\title{
Genetic control of intra-annual height growth in 6-year-old Norway spruce progenies in Latvia
}

\author{
Roberts Matisons ${ }^{(1)}$, \\ Pauls Zeltiņš ${ }^{(1)}$, \\ Darius Danusevičius ${ }^{(2)}$, \\ Baiba Džeringa ${ }^{(1)}$, \\ Iveta Desaine ${ }^{(1)}$, \\ Āris Jansons ${ }^{(1)}$
}

\section{Introduction}

The effect of climatic changes on forests varies regionally and locally (Wilmking et al. 2004, Lindner et al. 2010), raising challenges for management systems worldwide (Millar et al. 2007). In Northern Europe, warming is expected to enhance forest productivity via an extension of vegetation period and intensification of photosynthesis (Menzel \& Fabian 1999, Kolari et al. 2007), yet the increasing effects of water deficit and late/early frosts might notably counteract such improvements ( $\mathrm{Gu}$ et al. 2008, Lindner et al. 2010, Zeps et al. 2017). To mitigate the negative effects of a changing climate, an application of the improved

Coupling growth with periods of favourable weather conditions minimizes risks of frost damage and maximizes annual height increment. The phenology of the formation of height increment is therefore a trait related to the adaptability of trees to annual weather fluctuations. Strong genetic control of the timing of the onset and cessation of shoot elongation has been reported for Norway spruce, but little is known about its fluctuations that occur during the growth period. The strength of the genetic control of the height growth rate was assessed for young (6 years old) Norway spruce progenies originating from six open-pollinated stands from two local provenance regions. In 2010, the length of the growing period for the studied trees was ca. 60 days. Trees from the more continental provenance region, which had later onset and cessation of height growth (by ca. 2.5 days), exhibited slightly lower increments (by ca. $1 \%)$. Accordingly, the provenance region had a significant effect on height growth at the beginning and end of the growing period. Nevertheless, considerable genetic control of the growth rate was found throughout the entire growing period (particularly at the beginning and cessation, $h_{a}^{2} \geq 0.20$ ), except for a week-long interval around mid-summer $\left(h_{a}{ }^{2}=0.07\right)$. Similarly, the coefficient of additive genetic variation suggested that breeding could be applied for the improvement of height growth intensity throughout the season. The phenotypic correlations between weekly growth rates and tree height (before growth) were mostly non-significant, suggesting varying mechanisms of control, hence possibility for simultaneous improvement of the traits by breeding.

Keywords: Height Growth Rate, Growing Period, Heritability, Picea Abies, Local Populations

forest regeneration material has been advised (Lindner 2000, Bolte et al. 2009), emphasizing the importance of tree breeding for future forestry (Namkoong et al. 2012). Currently, tree breeders have focused mainly on traits related to growth capacity and stem quality (Ekberg et al. 1985, Hannerz 1993, Kroon et al. 2011), yet the traits related to adaptability appear particularly topical under shifting conditions (Hannerz 1998, Namkoong et al. 2012). Ekberg et al. (1985) showed that traits important for adaptation have higher within-population variability than growth capacity does; nevertheless, to include such traits in selection programmes, detailed information about
(1) Latvian State Forest Research Institute "Silava", Rigas str. 111, LV2169 Salaspils (Latvia); (2) Aleksandras Stulginskis University, Faculty of Forest Sciences and Ecology, Studentu 11, LT53361 Kaunas (Lithuania)

@ Roberts Matisons (robism@inbox.lv)

Received: Mar 06, 2018 - Accepted: Feb 06, 2019

Citation: Matisons R, Zeltinš P, Danusevičius D, Džerina B, Desaine I, Jansons A (2019). Genetic control of intra-annual height growth in 6-year-old Norway spruce progenies in Latvia. iForest 12: 214-219. - doi: 10.3832/ifor2777-012 [online 2019-04-25]

Communicated by: Andrea Piotti their genetic control is necessary.

Tree height is among the main traits related to the growth capacity and productivity of stands; hence, it has been used for the selection of best genotypes (Ekberg et al. 1985, Hannerz 1993, Danusevičius \& Gabrilavičius 2001, Kroon et al. 2011). The height increment of Norway spruce (Picea abies Karst.) is determined by the number of growth initials formed in the preceding year and their elongation (Cannell \& Johnstone 1978). In addition, "free", i.e., undetermined lammas growth (Cannell \& Johnstone 1978, Hannerz et al. 1999), which increases the productivity of stands (Neimane et al. 2015), can occur. The height growth of Norway spruce is seasonal, and most of the annual increment is formed rapidly during the first part of summer (Owens \& Molder 1984, Chmura 2006), although additional growth can occur afterwards, if conditions are favourable (Neimane et al. 2015).

The susceptibility of newly formed tissues (shoots) to environmental risks varies throughout the season, thus the coupling of periods of cell division and tissue maturation with favourable conditions is crucial for growth (Dietrichson 1969, Langvall \& Löfvenius 2002, Muffler et al. 2016). Accordingly, timing and intensity of growth, which vary geographically, seasonally, and 
depending on genetic and environmental factors (Slaney et al. 2007), can be considered as adaptive traits related to height growth and productivity (Hannerz et al. 1999). Such adaptive traits have been shown to have an even greater effect on the productivity of Norway spruce over a longer term than the traits related to growth capacity (Hannerz et al. 1999, Danusevičius \& Gabrilavičius 2001, Chmura 2006). In addition, traits related to the timing of growth are age-independent, hence are crucial for long-term predictions of tree responses (Hannerz et al. 1999).

The physiological activity and growth of Norway spruce are controlled primarily by photoperiod (Aronsson 1975, Partanen et al. 1998), while temperature causes certain shifts in the date of budburst and thus the initiation of the height increment (Hannerz 1999) and intensity of shoot elongation (Sarvas 1973, Danusevičius et al. 1999). In a warming climate, which also implies increasing variability in terms of weather extremes in springs (Avotniece et al. 2012), height growth can start earlier (Danusevičius et al. 1999), exposing newly formed shoots to damage from late frosts (Polle et al. 1996), particularly in the case of unsheltered trees, e.g., after clear cuts (Langvall \& Löfvenius 2002). The termination of height growth coincides with the initiation of cold hardening in response to the decreasing photoperiod (Dormling 1973, 1993, Beck et al. 2004). Accordingly, Danusevičius \& Gabrilavičius (2001) and Kohmann \& Johnsen (2007) showed that Norway spruce populations/clones with later onset and cessation of growth suffered considerably less frost damage, were more productive, and had better stem form. Such differences have been related to the requirements in terms of heat and day-length for the initiation and cessation of growth, which vary among provenances (Sarvas
1973, Danusevičius \& Gabrilavičius 2001). Considering the importance of phenology for the survival and adaptation of species, strong genetic control (heritability) has been estimated for the timing of budburst and growth cessation (Hannerz 1998, 1999, Hannerz et al. 1999), implying photoperiodic and thermal regulation. Nevertheless, the annual height increment is a result of continuous elongation and maturation processes; hence, detailed information about the genetic control of intra-annual shoot elongation can be helpful for a deeper assessment of the susceptibility of growth to environmental conditions (Skrøppa 1982). Ekberg et al. (1985) reported a slight increase in the genetic variance component of the height increment with the advance of the growing period for Norway spruce in populations in Sweden. Still, insufficient information is available on the genetic control of height growth during various stages of shoot elongation for other populations (Kroon et al. 2011).

The aim of this study was to assess the intra-annual height growth pattern and the strength of genetic control (heritability) of the height growth rate (GR) of Norway spruce individuals originating from the western and eastern provenance regions of Latvia. We hypothesized that genetic control fluctuated during the height growth period, being the highest at the initiation and cessation of growth. We also hypothesized that intra-annual GRs were not correlated with tree height, but rather controlled independently.

\section{Material and methods}

\section{Field trial and measurements}

A field trial of progenies of Norway spruce plus-trees from six open-pollinated stands (Fig. 1) representing two local provenance regions (western and eastern

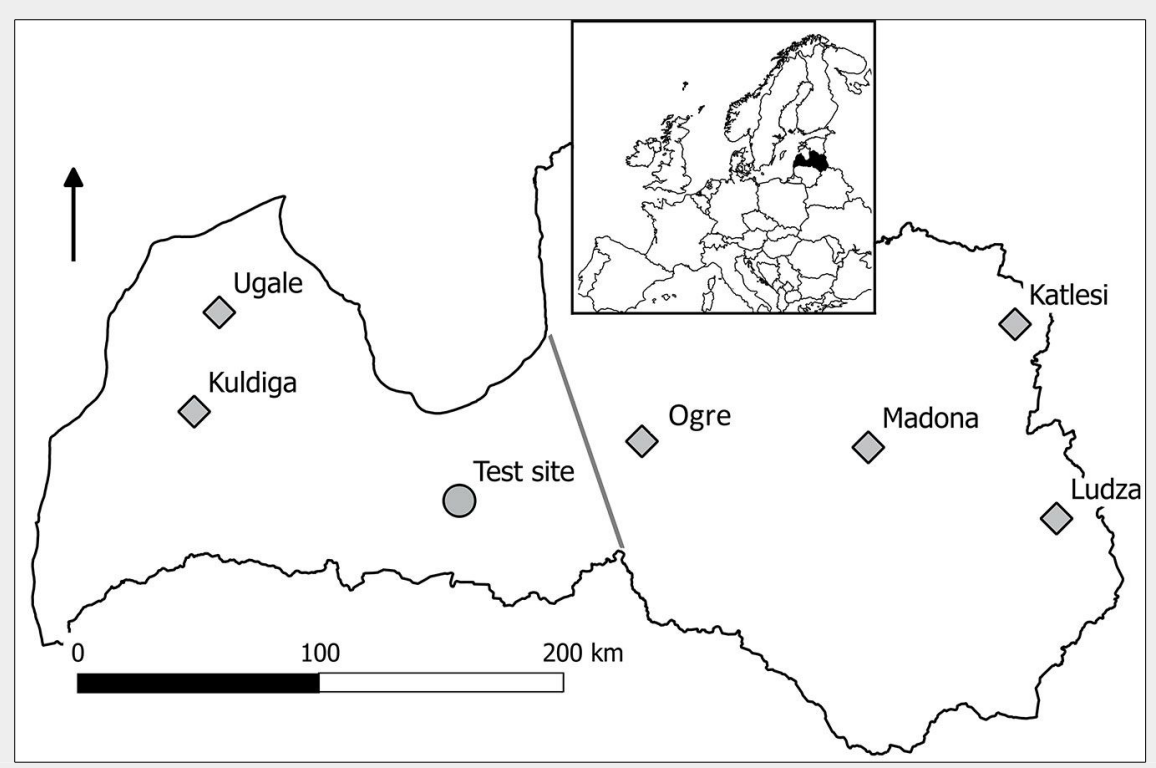

Fig. 1 - The provenances of the tested Norway spruce (squares) and location of the trial (circle). Grey line demarcate two provenance regions of Norway spruce in Latvia.
- Gailis 1993) from the western part of the species range was studied. The naturally regenerated seedlots (stands where seeds were collected) were growing in lowland conditions (50-150 m above sea level) on dry, mesotrophic mineral (silty or sandy) soils. The studied trial was established in 2006; two-year-old, bare-rooted seedlings were planted in forest land in dry, mesotrophic mineral soil (Hylocomiosa stand type). Ten open-pollinated half-sib families per seedlot (20 and 40 families representing the western and eastern provenance regions, respectively - Fig. 1) were tested. Each family was represented by five (for a few families, four) randomized replications of plots containing $4 \times 3$ trees (3190 trees planted in total; 48-60 trees per family). The spacing of trees was $3 \times 2 \mathrm{~m}$.

The climate in the central part of Latvia is moist continental (Lindner et al. 2010). During 2005-2015, the mean ( \pm standard deviation) annual temperature was $7.8 \pm 0.6{ }^{\circ} \mathrm{C}$; the mean monthly temperature ranged from $-3.5 \pm 3.3$ to $18.9 \pm 1.6{ }^{\circ} \mathrm{C}$ in January and July, respectively (Harris et al. 2014). The vegetation period, when mean diurnal temperatures exceeded $5{ }^{\circ} \mathrm{C}$, extended from mid-April to mid-October. The mean annual precipitation was $656 \pm 91 \mathrm{~mm}$, yet the highest monthly precipitation occurred during the summers (June-September period, ca. $75 \pm 30 \mathrm{~mm}$ per month). The climate in the central part of Latvia is warmer (annual temperature was ca. $1.5^{\circ} \mathrm{C}$ higher, and the vegetation period is longer by ca. 10 days) and drier (annual precipitation was ca. $150 \mathrm{~mm}$ lower) than both the western and eastern parts of the country (Harris et al. 2014). In 2010, the daily minimum temperature was constantly above $0{ }^{\circ} \mathrm{C}$ from May through September, although the beginning of May was warmer than the long-term mean for that period (Fig. 2a). The highest amount of precipitation occurred in July and August. The precipitation-free periods were up to a week long. During the growing period of 2010 (May 15Jul 31), the mean diurnal temperature and precipitation were $17.3 \pm 4.8{ }^{\circ} \mathrm{C}$ and 265 $\mathrm{mm}$, respectively, which were similar to the long-term means. During the July-September period in 2009, when the primordia of the studied increment were formed, the diurnal temperature ranged $14.0-29.7^{\circ} \mathrm{C}$, with the mean value of $16.2 \pm 2.6^{\circ} \mathrm{C}$; the mean 10-day precipitation sum was $17.5 \pm 15.4$ $\mathrm{mm}$.

Within the trial, 1273 trees (430 and 843 trees representing the western and eastern provenance regions, respectively) were selected for measurements. Forked and/or damaged trees were excluded. In 2010, at the age of six years, the lengths of the main shoots of the selected trees were measured every 6-8 days during the period from May 25 to July 20 (nine surveys) with a precision of $1 \mathrm{~mm}$. The measurements for all trees were done during the same day to reduce errors associated with growth. In addition, tree height after the cessation of 
Fig. 2 - Mean (black bold line), minimum and maximum (fine grey lines) daily temperature and precipitation (bars) at the trial site (a), mean height (b), and height growth rate of studied Norway spruce originating from the western and eastern regions of Latvia, and daylength (c) during the seventh growing period in 2010. In (b) and (c), whiskers indicate $95 \%$ confidence intervals. In

(c), the dates correspond to the last day of intervals, for which growth rates were calculated.
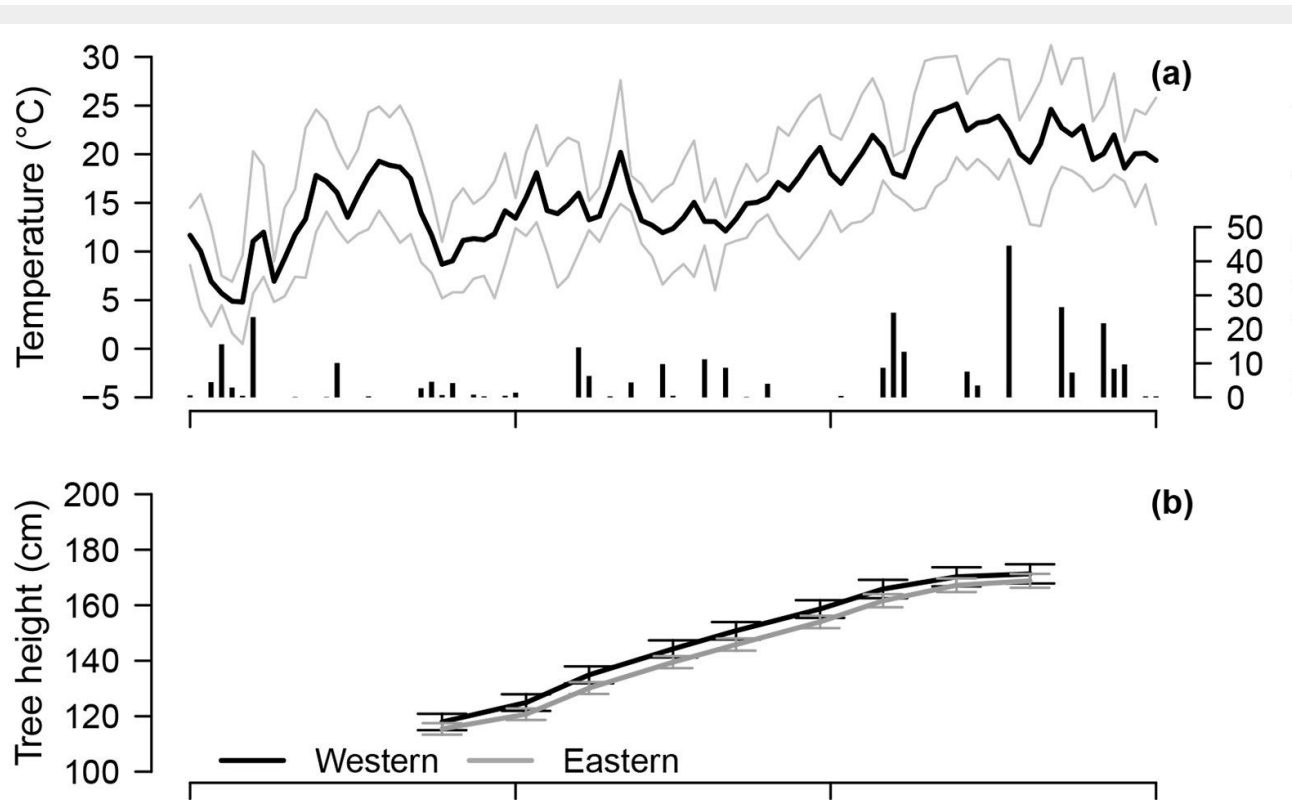

(b)

(c)

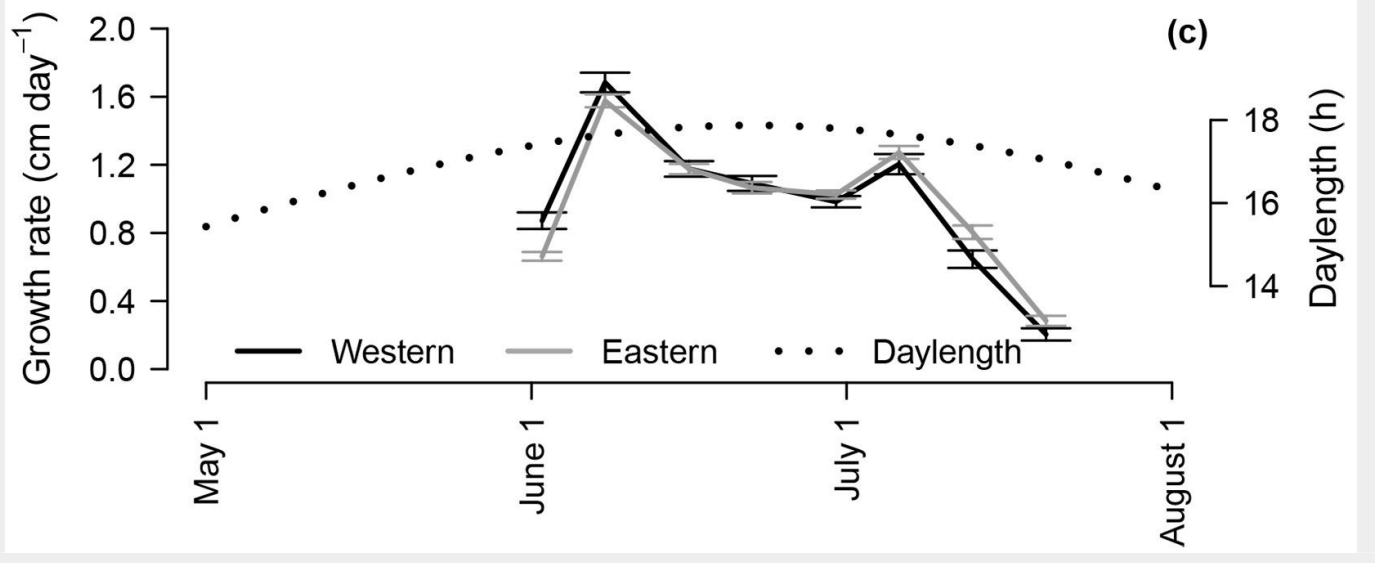

height growth (September 10) was measured.

\section{Data analysis}

For each tree, weekly GRs ( $\mathrm{mm}$ day $^{-1}$ ) were calculated. The effect of provenance region on the timing of growth initiation (as a binomial variable), weekly GRs, total height increment, and tree height at the beginning and end of the observation period was assessed using linear mixed models (Zuur et al. 2009) of the following form (eqn. 1):

$$
Y_{i j k}=\mu+P_{i}+\left(F_{j(i)}\right)+\left(R_{k}\right)+Z_{i j k 1}+E_{i j k}
$$

where $Y_{\mathrm{ijk}}$ was the response variable; $\mu$ was the overall mean; $P_{i}$ was the fixed effect of provenance region $i ;\left(F_{j(i)}\right)$ was the random effect of family $j$, nested within provenance region $i ;\left(R_{\mathrm{k}}\right)$ was the random effect of replication $k ; Z_{i j k 1}$ was the value of the response parameter in the preceding period (numeric covariate, where applicable); and $E_{i \mathrm{ijk}}$ was the residual error term. The differences in growth onset and cessation were assessed with a generalized model using a binomial distribution of the residuals and a "logit" link function. The analysis of variance of the models was used to determine the strength of the effect of provenance throughout the growing period.

For the assessment of the strength of the genetic control of intra-annual growth patterns (genetic parameters), which is based on the family and family $\times$ environment variance components, the models were transformed to (eqn. 2):

$Y_{i j k l}=\mu+P_{i}+R_{k}+\left(F_{j}\right)+\left(F_{j(i)} \cdot R_{k}\right)+Z_{i j k 1}+E_{i j k l}$

where $P_{\mathrm{i}}$ was the fixed effect of provenance region $i ; R_{k}$ was the fixed effect of replication $\mathrm{k} ;\left(F_{\mathrm{j}}\right)$ was the random effect of family $j ;\left(F_{j(i)} \cdot R_{k}\right)$ was the random effect of the family $\times$ replication interaction; $Z_{i \mathrm{jk} 1}$ was the value of the response parameter from the preceding period (numeric covariate, where applicable); and $E_{\mathrm{ijk}}$ was the residual error term.

The narrow sense (additive) individualtree heritability coefficient $\left(h_{a}{ }^{2}\right)$ for weekly $G R$, shoot length, and tree height was calculated based on family variance according to Falconer \& Mackay (1996 - eqn. 3)

$$
h_{a}^{2}=\frac{4 \cdot \hat{\sigma}_{f}^{2}}{\hat{\sigma}_{f}^{2}+\hat{\sigma}_{f b}^{2}+\hat{\sigma}_{e}^{2}}
$$

where $\hat{\sigma}_{f}{ }^{2}, \hat{\sigma}_{\mathrm{fb}}{ }^{2}$ and $\hat{\sigma}_{\mathrm{e}}{ }^{2}$ were the estimated variance components of family, family $\times$ replication interaction, and residual, respectively. The mean heritability at the family level $\left(h_{f}^{2}\right)$, which describes the representability of heritability of traits by the experimental design, was calculated as (eqn. 4):

$$
h_{a}^{2}=\frac{4 \cdot \hat{\sigma}_{f}^{2}}{\hat{\sigma}_{f}^{2}+\left(\hat{\sigma}_{f b}^{2} / r\right)+\left(\hat{\sigma}_{e}^{2} / r n\right)}
$$

where $r$ was the number of replications, and $n$ was the harmonic mean of the number of observations per plot. The standard errors for $h_{a}{ }^{2}$ and $h_{f}{ }^{2}$ were estimated using approximation by Dickerson (1969). The coefficient of additive genetic variation $\left(C V_{a}\right)$, which indicates the amount of variance in a trait that could be altered by breeding (Falconer \& Mackay 1996), was calculated as follows (eqn. 5):

$$
C V_{a}=\frac{\sqrt{\hat{\sigma}_{f}^{2}}}{\bar{\mu}}
$$

Phenotypic Pearson's correlation analysis based on individual observations as well as on family means was used to quantify the linkage among the studied traits. Trees were used as observations, and replication was considered to be the statistical unit. The analyses were conducted in SAS using 
Tab. 1 - The effect of provenance region on height growth rate during the growing period, tree height prior and after the height measurements in 2010, and genetic parameters: additive heritability coefficient $\left(h_{\mathrm{a}}{ }^{2}\right)$, family mean heritability coefficient $\left(h_{f}^{2}\right)$, and coefficient of additive genetic variation $\left(C V_{a}\right)$ for these traits. (SE): standard error.

\begin{tabular}{|c|c|c|c|c|c|c|}
\hline \multirow[t]{2}{*}{ Param } & \multirow[t]{2}{*}{ Period } & \multicolumn{2}{|c|}{$\begin{array}{l}\text { Effect of } \\
\text { provenance region }\end{array}$} & \multicolumn{2}{|c|}{ Genetic parameters } & \multirow[b]{2}{*}{$C V_{\mathrm{a}}$} \\
\hline & & $F$-value & $p$-value & $h_{\mathrm{a}}^{2} \pm \mathrm{SE}$ & $h_{f}^{2}$ & \\
\hline \multirow{8}{*}{$\begin{array}{l}\text { Height } \\
\text { growth } \\
\text { rate }\end{array}$} & May 25-June 2 & 8.11 & $<0.01$ & $0.73 \pm 0.16$ & 0.81 & 0.31 \\
\hline & June 2 -June 8 & 2.66 & 0.11 & $0.48 \pm 0.12$ & 0.66 & 0.11 \\
\hline & June 8-June 16 & 0.01 & 0.93 & $0.07 \pm 0.04$ & 0.21 & 0.06 \\
\hline & June 16 -June 22 & 0.22 & 0.66 & $0.24 \pm 0.08$ & 0.61 & 0.15 \\
\hline & June 22-June 30 & 1.35 & 0.26 & $0.28 \pm 0.09$ & 0.63 & 0.14 \\
\hline & June 30-July 6 & 1.55 & 0.21 & $0.31 \pm 0.04$ & 0.58 & 0.13 \\
\hline & July 6-July 13 & 4.42 & 0.03 & $0.61 \pm 0.18$ & 0.77 & 0.26 \\
\hline & July $13-J u l y ~ 20$ & 3.97 & 0.04 & $0.20 \pm 0.07$ & 0.50 & 0.48 \\
\hline \multirow[t]{3}{*}{$\begin{array}{l}\text { Tree } \\
\text { height }\end{array}$} & $\begin{array}{l}\text { In } 2009 \\
\text { (before observation) }\end{array}$ & 0.35 & 0.56 & $0.31 \pm 0.11$ & 0.65 & 0.11 \\
\hline & $\begin{array}{l}\text { In } 2010 \\
\text { (after observation) }\end{array}$ & 0.46 & 0.50 & $0.39 \pm 0.12$ & 0.71 & 0.08 \\
\hline & $\begin{array}{l}\text { Increment } \\
\text { (shoot length) }\end{array}$ & 0.27 & 0.65 & $0.30 \pm 0.10$ & 0.60 & 0.08 \\
\hline
\end{tabular}

PROC MIXED, PROC LIMMIX, and PROC CORR (SAS Institute Inc. 2004).

\section{Results}

During the seventh growing period, the mean tree height increased from $114.5 \pm 1.7$ to $169.6 \pm 2.0 \mathrm{~cm}$ (Fig. 2b). Trees from the western provenance region were slightly taller (ca. 1\%) compared with trees from the eastern region; yet, considering the experimental design (random effects, among which family and block had the highest variance), these differences were not significant ( $p$-value $>0.50$ ). The same was observed for total shoot length at the end of the seventh growing period.

The onset of height growth was significantly ( $p$-value $<0.01$ ) earlier for trees from the western provenance as compared to the eastern provenance region, because 68.7 and $51.7 \%$ of trees had initiated shoot elongation prior to the first measurement on May 25, respectively. A significant difference ( $p$-value $<0.05$ ) was also observed for growth cessation, because $36.6 \%$ and $28.2 \%$ of trees from the western and eastern provenance regions had completed height increment (showed zero GR) prior to the final measurement on July 20, respectively. Accordingly, the height growth period was estimated to be ca. 60 days long (mean GR $\left.=0.92 \pm 0.02 \mathrm{~cm} \mathrm{day}^{-1}\right)$, and it occurred when the day-length was $\geq 16.5 \mathrm{~h}$ (Fig. $2 \mathrm{C}$ ).

In 2010, shoot growth was faster during the first part of the season (Fig. 2C), and $50 \%$ of the height increment were completed around the $17^{\text {th }}$ of June (ca. 25 days since growth onset). Initiation and cessation of the height growth of trees from the western provenance region appeared ca. 2 days earlier. Accordingly, they showed significantly higher $G R$ at the beginning and significantly lower GR at the cessation of the growing period. Although GR showed a decreasing tendency after June 8 , a sudden improvement in growth, irrespective of provenance region, was observed during the first week of July, which coincided with a warmer and dryer period (Fig. 2a).

The effect of provenance region on $G R$ varied during the season (Tab. 1). The strongest provenance effect was observed at the beginning and at the cessation of the growing period (before June 3 and after July 6; p-values < 0.05), while it was weak around mid-summer ( $p$-value $>0.21$ ). A similar seasonal pattern was observed for the additive heritability, as the highest $h_{a}{ }^{2}$ coefficients $(>0.30)$ were observed at the beginning and end of the season. Nevertheless, during the mid-part of the growing period, $h_{a}{ }^{2}$ remained mostly intermediate (Falconer \& Mackay 1996). The $h_{f}{ }^{2}$ was generally higher (mean $h_{f}{ }^{2}=0.60$ ) and less variable throughout the season. The pattern of $C V_{a}$ was similar to the effect of provenance region, ranging from 0.06 to 0.48 in the middle and at the end of the growing period, respectively. The heritability for tree height and shoot length was high $\left(h_{a}{ }^{2} \geq 0.31\right.$ and $\left.h_{f}{ }^{2} \geq 0.65\right)$, yet the genetic variation in these traits was low $\left(C V_{a} \leq\right.$ 0.11).

Significant phenotypic correlations were observed among the studied traits. The height increment of 2010 was strongly correlated with the terminal tree height $(r=$ 0.56 , p-value $<0.001$ ), yet the correlation with the initial height of trees was considerably weaker, although significant $(r=$ 0.10 , p-value < 0.01). Similarly, the GRs throughout the season were positively correlated with the terminal tree height (mean $r=0.35$ ), yet the correlations with the tree height prior to the growing period were mostly non-significant (mean $r=0.07$ - Tab. 2). The correlations among the weekly GRs ranged from -0.14 to 0.67 and had an explicit tendency to decrease with an increasing interval between the measurements due to the autocorrelation of growth. Nevertheless, the similarity of GRs in consecutive periods was higher during

Tab. 2 - Phenotypic Pearson's correlation coefficients (the upper diagonal part) and their p-values (the lower diagonal part) among the height growth rate (GR) and tree height before and after growing period of 2010.

\begin{tabular}{|c|c|c|c|c|c|c|c|c|c|c|}
\hline Parameter, Period & 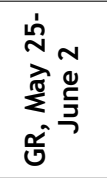 & 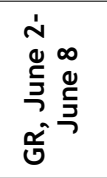 & 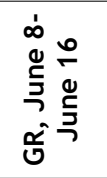 & 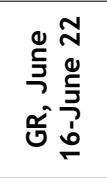 & 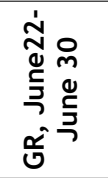 & 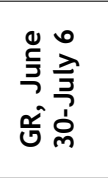 & 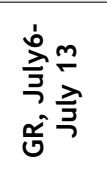 & 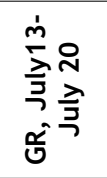 & 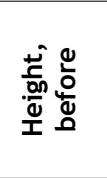 & 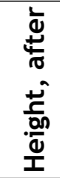 \\
\hline GR, May 25-June 2 & - & 0.47 & 0.18 & 0.21 & 0.07 & 0.02 & -0.12 & -0.14 & 0.02 & 0.22 \\
\hline GR, June 2-June 8 & $<0.001$ & - & 0.19 & 0.47 & 0.39 & 0.35 & 0.25 & 0.04 & 0.07 & 0.38 \\
\hline GR, June 8-June 16 & $<0.001$ & $<0.001$ & - & 0.21 & 0.54 & 0.47 & 0.39 & 0.15 & 0.03 & 0.31 \\
\hline GR, June 16-June 22 & $<0.001$ & $<0.001$ & $<0.001$ & - & 0.51 & 0.48 & 0.41 & 0.16 & 0.04 & 0.34 \\
\hline GR, June 22 -June 30 & 0.01 & $<0.001$ & $<0.001$ & $<0.001$ & - & 0.67 & 0.63 & 0.29 & 0.04 & 0.41 \\
\hline GR, June 30 -July 6 & 0.43 & $<0.001$ & $<0.001$ & $<0.001$ & $<0.001$ & - & 0.62 & 0.29 & 0.16 & 0.48 \\
\hline GR, July 6-July 13 & $<0.001$ & $<0.001$ & $<0.001$ & $<0.001$ & $<0.001$ & $<0.001$ & - & 0.42 & 0.16 & 0.45 \\
\hline GR, July 13 -July 20 & $<0.001$ & 0.14 & $<0.001$ & $<0.001$ & $<0.001$ & $<0.001$ & $<0.001$ & - & 0.06 & 0.24 \\
\hline Height, before & 0.58 & 0.01 & 0.34 & 0.17 & 0.13 & $<0.001$ & $<0.001$ & 0.05 & - & 0.88 \\
\hline Height, after & $<0.001$ & $<0.001$ & $<0.001$ & $<0.001$ & $<0.001$ & $<0.001$ & $<0.001$ & $<0.001$ & $<0.001$ & - \\
\hline
\end{tabular}


the second part of the growing period from June 22 to July 13 . The family mean correlations (not shown) showed a highly similar pattern, although family mean GRs in the May 5-June 2 period and those later periods were negatively correlated.

\section{Discussion}

The height increment of Norway spruce (Fig. 2) was similar to that in other stands within the region (Rone 1984, Neimane et al. 2015). Although Gailis (1993) observed a faster height growth for Norway spruce from eastern Latvia, the lack of such a difference in the studied trial might be related to similar transfer distances (Fig. 1) or to the effects of a drier climate at the trial site. In addition, Norway spruce from both provenance regions had growing periods of similar length (ca. 60 days), explaining the comparable height increments.

The height growth patterns of Norway spruce from both provenance regions were similar. The highest GR was observed at the beginning of the growing period, followed by a gradual decrease (Fig. 2c) that can be related to the concentration of growth hormones after the onset of growth (Pallardy 2008). The additional lammas growth, which occurred during the June 30-July 6 period, irrespectively of provenance region, was likely triggered by the increased temperature and solar radiation following the period of cooler and more humid weather (low precipitation Odin 1972, Cannell \& Johnstone 1978, Neimane et al. 2015).

Although the pattern of height growth of the studied Norway spruce was similar (Fig. 2), the phenology differed by provenance region (Tab. 1), indicating possible local adaptations to climate, as the photoperiod was the same. The specifics of the temperature-related control mechanisms have been identified as the main cause of longitudinal differences in growth phenology of Norway spruce (Heide 1974, Hannerz 1998), even on a small geographic scale (<300 km - Danusevičius \& Persson 1998). The Norway spruce from the eastern part of Latvia, where the climate was harsher, had significantly later onset and cessation of height growth (Tab. 1), indicating better adaptation to the late frosts ( $\mathrm{Di}$ etrichson 1969, Polle et al. 1996, Langvall \& Löfvenius 2002). Accordingly, the provenance region had a stronger effect on the timing of growth onset than cessation, in contrast to the findings of Ekberg et al. (1985) in central Sweden. Apparently, in the milder climate of the Baltic States (compared with central Sweden), where summers are warmer, the late frosts mainly have had an effect on Norway spruce growth (particularly in the eastern part of Latvia - Rone 1984), thus determining a stronger genetic control of growth onset (Tab. 1). The increasing effect of late frosts on plant growth has been attributed to the warming of climate (Gu et al. 2008). Nevertheless, the genetic control of GR, as illus- trated by the differences between the provenance regions (Tab. 1), was significant only during rather short periods after the onset and before the cessation of growth, likely following the probability of frosts (Avotniece et al. 2012). During the period of fastest height growth in June 822, GR was controlled mainly by external factors, as noted previously by Danusevičius et al. (1999), while the differences between the provenance regions were negligible (Tab. 1).

The studied traits showed high heritability, as the $h_{a}^{2}$ mostly exceeded 0.20 (Tab. 1), implying that they might be improved by breeding (Falconer \& Mackay 1996). The reliability of the genetic parameters calculated based on the studied trait was good, as the $h_{f}^{2}$ (Tab. 1) prevailingly exceeded 0.50 (Falconer \& Mackay 1996). Considering the additive genetic variation of the studied traits $\left(C V_{a}-\right.$ Tab. 1), the highest effect of breeding might be expected for the $G R$ at the beginning and cessation of growth, as also shown by the differences among the provenance regions. Nevertheless, the heritability of GR during the middle of summer did not reach minimum values (except for the GR in the period June 8-16), suggesting that these traits might be influenced by selection at the family level. Tree height showed high $h_{a}{ }^{2}$ values, yet the $C V_{a}$ was low, as observed in similar studies, indicating strong genetic control but limited variability (Hannerz et al. 1999). The GR throughout the season was independent of tree height (Tab. 2), allowing for selection for productivity and adaptability. The increment of trees is autoregressive (Cook 1985), and such a pattern was observed for the intra-annual GR (Tab. 2). Nevertheless, stronger correlations between consecutive GRs during the middle compared with the cessation of the growing period might be explained by the utilization of current assimilates for growth (Axelsson \& Axelsson 1986).

\section{Conclusions}

The studied provenances of Norway spruce showed similar height increments, intra-annual height growth patterns, and length of growing period, yet they differed by growth phenology, indicating adaptation to slightly different climates. Considering that phenology is a trait that is highly important for adaptation, the intensity of growth (GR) throughout the season showed strong genetic control, particularly at the beginning and cessation of the growing period, when the probability of frost was the highest. The control mechanisms of growth phenology (and intensity of height growth during the season) and growth capacity (total annual height increment) appeared to be independent, suggesting that both traits might be simultaneously improved by tree breeding to increase the productivity and sustainability of Norway spruce under a changing climate.

\section{Acknowledgements}

The study was financed by European Regional Development Fund, support for post-doctoral studies in Latvia "Plasticity of development and xylogenesis of the native and introduced tree species under changing climate" (No.: 1.1.1.2.VIAA/1/16/108). Sampling and data collection was done under the framework of JSC "Latvijas valsts meži" project "Adaptation of forestry to climatic changes". Endijs Baders and Andis Adamovičs helped during the data collection.

\section{References}

Aronsson A (1975). Influence of photo- and thermoperiod on initial stages of frost hardening and dehardening of phytotron-grown seedlings of Scots pine (Pinus sylvestris L.) and Norway spruce (Picea abies (L.) Karst.). Studia Forestalia Suecica 128: 1-20. [online] URL: http://pub.ep silon.slu.se/5647/

Avotniece Z, Klavinš M, Rodinovs V (2012). Changes of extreme climate events in Latvia. Environmental and Climate Technologies 9: 412. [online] URL: http://www.degruyter.com/ downloadpdf/j/rtuect.2012.9.issue/v10145-0120010-1/v10145-012-0010-1.pdf

Axelsson E, Axelsson B (1986). Changes in carbon allocation patterns in spruce and pine trees following irrigation and fertilization. Tree Physiology 2: 189-204. - doi: 10.1093/treephys/2. 1-2-3.189

Beck EH, Heim R, Hansen J (2004). Plant resistance to cold stress: mechanisms and environmental signals triggering frost hardening and dehardening. Journal of Bioscience 29: 449459. - doi: 10.1007/BF02712118

Bolte A, Ammer C, Löf M, Madsen P, Nabuurs GJ, Schall P, Spathelf P, Rock J (2009). Adaptive forest management in central Europe: climate change impacts, strategies and integrative concept. Scandinavian Journal of Forest Research 24: 473-482. - doi: 10.1080/02827580903418224 Cannell MGR, Johnstone RCB (1978). Free or lammas growth and progeny performance in Picea sitchensis. Silvae Genetica 27: 248-255. [online] URL: http://www.sauerlaender-verlag. com/CMS/fileadmin/content/dokument/archiv/s ilvaegenetica/27_1978/27-6-248.pdf

Chmura DJ (2006). Phenology differs among Norway spruce populations in relation to local variation in altitude of maternal stands in the Beskidy Mountains. New Forests 32: 21-31. - doi: 10.1007/s11056-005-3390-2

Cook ER (1985). A time series approach to treering standardization. Dissertation, University of Arizona, Tucson, Arizona, USA, pp. 180.

Danusevičius D, Persson B (1998). Phenology of natural Swedish populations of Picea abies as compared with introduced seed sources. Forest Genetics 5: 211-220.

Danusevičius D, Jonsson A, Eriksson G (1999). Variation among open-pollinated families of Picea abies (L.) Karst. in response to simulated frost desiccation. Silvae Genetica 48: 158-167. [online] URL: http://www.sauerlaender-verlag. com/CMS/fileadmin/content/dokument/archiv/s ilvaegenetica/48_1999/48-3-4-158.pdf

Danusevičius D, Gabrilavičius R (2001). Variation in juvenile growth rhythm among Picea abies 
provenances from the Baltic States and adjacent regions. Scandinavian Journal of Forest Research 16: 305-317. - doi: 10.1080/0282758015 2496696

Dickerson GE (1969). Techniques for research in quantitative animal genetics. In: "Techniques and Procedures in Animal Science Research". American Society of Animal Science, Albany, NY, USA, pp. 36-79.

Dietrichson J (1969). The geographic variation in spring-frost resistance and growth cessation in Norway spruce (Picea abies (L.) Karst.). Norske Skogforsøksvesen 27: 91-104.

Dormling I (1973). Photoperiodic control of growth and growth cessation in Norway spruce seedlings. In: Proceedings of IUFRO meeting "Dormancy in Trees". Kórnik (Poland) 5-9 Sept 1973. Polish Academy of Sciences, Warsaw, Poland, pp. 1-16.

Dormling I (1993). Bud dormancy, frost hardiness and frost drought in seedlings of Pinus sylvestris and Picea abies. In: "Advances in cold hardiness" ( $\mathrm{Li} \mathrm{PH}$, Christersson L eds.), CRC Press, Ontario, Canada, pp. 285-298. [online] URL: http://books.google.com/books?id=TJxGD WAAQBAJ

Ekberg I, Eriksson G, Weng Y (1985). Betweenand within-population variation in growth rhythm and plant height in four Picea abies populations. Studia Forestalia Suecica 167: 1-14. [online] URL: http://pub.epsilon.slu.se/4697/

Falconer DS, Mackay TFC (1996). Introduction to quantitative genetics ( $4^{\text {th }}$ edn). Longman Group Ltd., London, UK, pp. 465.

Gailis A (1993). Norway spruce provenances in Latvia. In: Proceedings of IUFRO (S2.2-11) Symposium on "Norway Spruce Provenances and Breeding". Salaspils (Latvia) 14-18 Sept 1993. State Forest Research Institute "Silava", Salaspils, Latvia, pp 44-50.

Gu L, Hanson PJ, Post WM, Kaiser DP, Yang B, Enami R, Pallardy SG, Meyers T (2008). The 2007 Eastern US spring freeze: increased cold damage in a warming world? Bioscience 58: 253-262. - doi: 10.1641/B580311

Hannerz M (1993). Norway spruce provenances in central Sweden height growth and damage in a 12-year-old provenance trial in southern Gästrikland. Reports of the Forest Research Institute of Sweden 1: 1-23. [in Swedish with English summary] [online] URL: http://www.osti. gov/etdeweb/biblio/6605468

Hannerz M (1998). Genetic and seasonal variation in hardiness and growth rhythm in boreal and temperate conifers - a review and annotated bibliography. Reports of the Forest Research Institute of Sweden 2: 1-140.

Hannerz M (1999). Evaluation of temperature models for predicting bud burst in Norway spruce. Canadian Journal of Forest Research 29: 9-19. - doi: 10.1139/x98-175

Hannerz M, Sonesson J, Ekberg I (1999). Genetic correlations between growth and growth rhythm observed in a short-term test and performance in long-term field trials of Norway spruce. Canadian Journal of Forest Research
29: 768-778. - doi: 10.1139/x99-056

Harris I, Jones PD, Osborn TJ, Lister DH (2014). Updated high-resolution grids of monthly climatic observations the CRU TS3.10 Dataset. International Journal of Climatology 34: 623-642. doi: 10.1002/joc.3711

Heide OM (1974). Growth and dormancy in Norway spruce ecotypes (Picea abies). I. Interaction of photoperiod and temperature. Physiologia Plantarum 30: 1-12. - doi: 10.1111/j.1399-3054. 1974.tbo4983.x

Kohmann K, Johnsen O (2007). Effects of early long-night treatment on diameter and height growth, second flush and frost tolerance in two-year-old Picea abies container seedlings. Scandinavian Journal of Forest Research 22: 375-383. - doi: 10.1080/02827580701520486 Kolari P, Lappalainen $\mathrm{H}$, Hänninen $\mathrm{H}$, Hari $\mathrm{P}$ (2007). Relationship between temperature and the seasonal course of photosynthesis in Scots pine at northern timberline and in southern boreal zone. Tellus 59: 542-552. - doi: 10.1111/j.16000889.2007.00262.x

Kroon J, Ericsson T, Jansson G, Andersson B (2011). Patterns of genetic parameters for height in field genetic tests of Picea abies and Pinus sylvestris in Sweden. Tree Genetics and Genomes 7: 1099-1111. - doi: 10.1007/s11295-0110398-y

Langvall O, Löfvenius MO (2002). Effect of shelterwood density on nocturnal near-ground temperature, frost injury risk and budburst date of Norway spruce. Forest Ecology and Management 168: 149-161. - doi: 10.1016/S03781127(01)00754-X

Lindner M (2000). Developing adaptive forest management strategies to cope with climate change. Tree Physiology 20: 299-307. - doi: 10.1093/treephys/20.5-6.299

Lindner M, Maroschek M, Netherer S, Kremer A, Barbati A, Garcia-Gonzalo J, Seidl R, Delzon S, Corona P, Kolström M, Lexer MJ, Marchetti M (2010). Climate change impacts, adaptive capacity, and vulnerability of European forest ecosystems. Forest Ecology and Management 259 (4): 698-709. - doi: 10.1016/j.foreco.2009. 09.023

Menzel A, Fabian P (1999). Growing season extended in Europe. Nature 397: 659-659. - doi: 10.1038/17709

Millar Cl, Stephenson NL, Stephens SL (2007). Climate change and forests of the future: managing in the face of uncertainty. Ecological Applications 17: 2145-2151. - doi: 10.1890/06-1715.1 Muffler L, Beierkuhnlein C, Aas G, Jentsch A, Schweiger AH, Zohner C, Kreyling J (2016). Distribution ranges and spring phenology explain late frost sensitivity in 170 woody plants from the Northern Hemisphere. Global Ecology and Biogeography 25 (9): 1061-1071. - doi: 10.1111/ geb.12466

Namkoong G, Kang HC, Brouard JS (2012). Tree breeding: principles and strategies. Monographs on Theoretical and Applied Genetics 11, Springer Verlag, New York, USA, pp. 180. [online] URL: http://books.google.com/books?id=
IMjcBwAAQBAJ

Neimane U, Zadina M, Sisenis L, Dzerina B, Pobiarzens A (2015). Influence of lammas shoots on productivity of Norway spruce in Latvia. Agronomy Research 13: 354-360. [online] URL: http://agronomy.emu.ee/vol132/13_2_10_B5.pdf Odin H (1972). Studies of increment rhythm of Scots pine and Norway spruce. Studia Forestalia Suecica 97: 1-32.

Owens JN, Molder M (1984). The reproductive cycle of interior spruce. Ministry of Forests, British Columbia, Canada, pp. 29.

Pallardy SG (2008). Physiology of woody plants ( $3^{\text {rd }}$ edn). Elsevier, London, UK, pp. 464.

Partanen J, Koski V, Hänninen H (1998). Effects of photoperiod and temperature on the timing of bud burst in Norway spruce (Picea abies). Tree Physiology 18: 811-816. - doi: 10.1093/tree phys/18.12.811

Polle A, Kröniger W, Rennenberg H (1996). Seasonal fluctuations of ascorbate-related enzymes: acute and delayed effects of late frost in spring on antioxidative systems in needles of Norway spruce (Picea abies L.). Plant and Cell Physiology 37: 717-725. - doi: 10.1093/oxfordjour nals.pcp.a029005

Rone V (1984). Pirmie eglu provenienču vertešanas rezultati Latvija [First results from Norway spruce provenance trials in Latvia]. Jaunakais Mežsaimnieciba 26: 33-38. [in Latvian with English abstract]

Sarvas R (1973). Annual development cycle of forest trees. In: Proceedings of IUFRO meeting "Dormancy in Trees". Kórnik (Poland) 5-9 Sept 1973. Polish Academy of Sciences, Warsaw, Poland, pp. 122-131.

SAS Institute Inc. (2004). SAS/ETS 9.1 User's guide. SAS Institute Inc., Cary, NC, USA.

Skrøppa T (1982). Genetic variation in growth rhythm characteristics within and between natural populations of Norway spruce. A preliminary report. Silva Fennica 16: 160-167.

Slaney M, Wallin G, Medhurst J, Linder S (2007). Impact of elevated carbon dioxide concentration and temperature on bud burst and shoot growth of boreal Norway spruce. Tree Physiology 27: 301-312. - doi: 10.1093/treephys/27.2.301 Wilmking M, Juday GP, Barber VA, Zald HJ (2004). Recent climate warming forces contrasting growth responses of white spruce at treeline in Alaska through temperature thresholds. Global Change Biology 10: 1724-1736. - doi: 10.1111/j.1365-2486.2004.00826.x

Zeps M, Jansons A, Matisons R, Stenvall N, Pulkkinen $P$ (2017). Growth and cold hardening of European aspen seedlings in response to an altered temperature and soil moisture regime. Agricultural and Forest Meteorology 242: 47-54. - doi: 10.1016/j.agrformet.2017.04.015

Zuur AF, leno EN, Walker NJ, Saveliev AA, Smith GM (2009). Mixed effects models and extensions in ecology with R. Springer, New York, USA, pp. 574. [online] URL: http://books.goo gle.com/books?id=vQUNprFZKHsC 